\title{
Synthesis of Double $C$-Glycoside Analogue of sTn
}

\author{
Dino K. Ress ${ }^{\dagger}$, Sultan N. Baytas ${ }^{\ddagger}$, Qun Wang $^{\dagger}$, Eva M. Muñoz ${ }^{\ddagger}, K^{2}$ azuo Tokuzoki ${ }^{\S}$, Hiroshi \\ Tomiyama§, and Robert J. Linhardt ${ }^{\star}, \dagger, \ddagger$ \\ Department of Chemistry and Chemical Biology, Department of Biology and Department of \\ Chemical and Biological Engineering, Rensselaer Polytechnic Institute, Troy, New York 12180, \\ Division of Medicinal and Natural Product Chemistry, The University of lowa, lowa City, lowa \\ 52242, and Kotobuki Pharmaceutical Co., Ltd., Nagano, Japan
}

\section{Abstract}

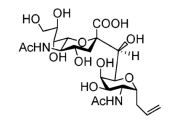

A sTn double $C$-glycoside, sTn analogue 2, was synthesized using samarium chemistry developed in our laboratory. Complications in the oxidation reaction affording aldehyde acceptor were overcome by double protection of amide and the use of a room-temperature ionic liquid as solvent. Studies are underway to conjugate the sTn double $C$-glycoside hapten $\mathbf{2}$ to KLH carrier protein for biological evaluation as a vaccine.

\begin{abstract}
Neuraminic acids are biologically important since they occupy the terminal position of the glycans on macro-molecules outside cells and cell membranes and are involved in recognition, cell interactions, neuronal transmission, ion transport, reproduction, differentiation, epitope masking, and protection. Neuraminic acids are also involved in pathological processes including infection, inflammations, cancer, and neurological, cardiovascular, endocrinological, and autoimmune diseases. ${ }^{1,2}$ Cell surfaces containing these terminal neuraminic acids interact with receptors, hormones, enzymes, toxins, and viruses and other pathogens that use Neu5Ac to localize on the surface of cells they infect. ${ }^{3}$ The linkage of neuraminic acid to glycoconjugates is among the most labile glycosidic linkages and is cleaved in vitro under mildly acidic conditions. In vivo, neuraminic acidcontaining glycoconjugates are catabolized through the removal of the terminal sialic acid residue by the action of hydrolase-type enzymes called neuraminidases. A non-hydrolyzable glycosidic linkage to neuraminic acid represents is an attractive approach to design reagents for glycobiology and immunology. The replacement of the interglycosidic oxygen atom with a hydroxymethylene group using $\mathrm{SmI}_{2}$ chemistry ${ }^{4}$ affords a class of hydrolytically and
\end{abstract}

\footnotetext{
(C) 2005 American Chemical Society

*To whom correspondence should be addressed. Phone: 518-276-3404. Fax: 518-276-3405. linhar@ rpi.edu.

†The University of Iowa.

†Rensselaer Polytechnic Institute.

$\S_{\text {Kotobuki Pharmaceutical Co., Ltd. }}$

Supporting Information Available: 1D and 2D H NMR spectra for compounds 2, 4a, 5-11, and 13; ${ }^{13} \mathrm{C}$ NMR spectra for compound 13, and X-ray data for compound $\mathbf{4 b}$. This material is available free of charge via the Internet at http://pubs.acs.org.
} 
metabolically inert $C$-glycoside analogues of natural glycoconjugates. ${ }^{5}$ This stable linkage is being studied to improve our understanding of biological recognition and to enhance or suppress biological events at the molecular level.

The development of vaccines against carbohydrates is of crucial importance in the fields of therapeutic glycobiology and immunology. ${ }^{6}$ A significant portion of the antitumor response against cancers involves carbohydrate tumor antigens. ${ }^{7}$ Microorganisms often express carbohydrate antigens and the immune response of the host to these antigens is an important mechanism of defense. ${ }^{8}$ One approach for improving carbohydrate antigens that has not been thoroughly explored is vaccination over an extended length of time using a catabolically stable $C$-glycoside vaccine. ${ }^{9}$ These agents might be useful in preparing immunogens for active immunization against neuraminic acid containing glycoconjugates in the design and preparation of antiviral, ${ }^{10}$ antibacterial, ${ }^{11}$ and anticancer vaccines. ${ }^{12}$

Sialyl-Tn, [a-D-Neu5Ac- $(2 \rightarrow 6)$ a-D-GalNAc- $(1 \rightarrow O)-\operatorname{Ser} / \mathrm{Thr}$ ] (sTn 1a, Figure 1) is found on the HIV envelope glycoprotein gp $120^{13}$ and in tumor-associated antigens present in the glycoproteins on the surface of cancer cells, including those associated with carcinomas of the breast, prostate, pancreas, colon, ovary, lung, and stomach. ${ }^{14}$ The sTn antigen is wellknown as a prognostic indicator and has proven to be an effective target for therapy of cancers. Conjugate vaccines of sTn-KLH (keyhole limpet hemocyanin carrier protein ${ }^{15}$ ) showed remarkable immunogenicity, resulting in the production of both IgM- and IgG- type antibodies. ${ }^{16}$ The sTn $C$-glycoside $\mathbf{1 b}$ has been synthesized in our laboratory in 15 steps, ${ }^{17}$ and its KLH-conjugate is currently under biological evaluation.

An sTn double $C$-glycoside analogue 2 (Figure 1) was designed to (1) reduce the number of synthetic steps required to synthesize $\mathbf{1 b}$; (2) to facilitate its conjugation to KLH; and (3) to further increase biological half-life and enhance immunological response.

Starting from $\mathrm{N}$-acetylglucosamine, the a-C-glycoside derivative $\mathbf{3}$ was prepared by a literature method. ${ }^{18}$ Compound 3 was protected as the 6-TBDPS silyl ether and 3,4isopropylidinated, and then the TBDPS protection at 6-position was removed to afford 4a in good yield. Swern oxidation of the 6-hydroxy group, unexpectedly failed to afford the desired 6-formyl galactoside 6. ${ }^{1}$ HNMR spectroscopy instead revealed the formation of the bicyclic compound 5 (Scheme 1).

The formation of lactol ring in $\mathbf{5}$ would require a change in the configuration at either C-2 or $\mathrm{C}-5$ of the galacto ring. Extensive $2 \mathrm{D}-{ }^{1} \mathrm{H}$ NMR studies suggested that the stereochemistry at C-2 had been altered giving the tallo form of the sugar. Thus, the prior synthesis of $\mathbf{3}$ and its characterization ${ }^{18}$ was brought into question. X-ray crystallography analysis had been performed to establish the absolute stereochemistry of $\mathbf{4 b}$ and provide an unambiguous assignment of its stereogenic centers. The resulting crystal structure that the configuration of C-5 had instead been inverted. We rationalized that under slightly basic conditions in the presence of triethylamine aldehyde $\mathbf{6}$ undergoes enolization and the enolate intermediate epimerizes at C-5. A change in ring conformation from ${ }^{4} \mathrm{C}_{1}$ to ${ }^{4} \mathrm{~B}^{1}$ would place the weakly nucleophilic $\mathrm{N}$-acetamido functional group in close proximity to the 5-formyl electrophile. Intramolecular attack of the nitrogen ion pair on the adjacent aldehyde leads to the bicyclic 
zwitterionic hemiaminal that on proton transfer affords the cyclic hemiaminal product 5 . Various oxidants such as PCC and TPAP also failed to give the desired 6-formyl derivative 6. Hypervalent iodine reagents are known to accomplish chemoselective oxidations under neutral conditions. 6-Hydroxy analogue 4a was treated with 1.5 equiv of the Dess-Martin periodinane reagent in the presence of molecular sieves in $\mathrm{CH}_{2} \mathrm{Cl}_{2}$. A number of different workup procedures were examined, but in the best case, the desired compound 6 was isolated in less than $10 \%$ yield. Exposure to even the most mildly basic conditions appears to catalyze C-5 epimerization leading to the cyclic hemiaminal product $\mathbf{6}$. We theorized that derivatizing the $\mathrm{N}$-acetamido group as a diamide would deter the cyclization. In addition, to sterically hindering attack of the aldehyde by the $N$-acetamide, a second acyl protecting group would further reduce the nucleophilicity of the nitrogen, preventing epimerization and subsequent cyclization. One concern about the approach was whether it would be possible to selectively remove the benzoyl substituent while leaving the $N$-acetyl group in place. Wong and co-workers, however, had successfully demonstrated $p$-halobenzoyl ester as suitable protecting group in carbohydrate synthesis. ${ }^{19}$

The 6-hydroxyl group in compound $\mathbf{3}$ was protected as the TBDPS silyl ether $\mathbf{7}$ and 3,4isopropylidinated to afford $\mathbf{8}$ in good yield. Treatment of $\mathbf{8}$ with $p$-chlorobenzoyl chloride in a 1:1 mixture of pyridine and $\mathrm{CH}_{2} \mathrm{Cl}_{2}$ giving 9 in good yield (92\%). Chemoselective removal of TBDPS using tetrabutylammonium flouride (TBAF) in the presence of an excess or equimolar amount of acetic acid resulted in decomposition. When the milder trihydrofluoride triethylamine was used, the corresponding alcohol $\mathbf{1 0}$ was formed quantitatively. After desilylation, we decided to explore very mild options for Dess-Martin oxidation to completely prevent C-5 epimerization. Hypervalent iodine reagent in ionic liquids reportedly leads to mild chemoselective and in some cases regioselective oxidative transformations. ${ }^{20}$ Our laboratory had previously used ionic liquids in synthetic carbohydrate chemistry. ${ }^{21}$ Compound $\mathbf{1 0}$ was dissolved in 1-butyl-3-methylimidazolium tetrafluoroborate $\left([\mathrm{bmim}]^{+} \mathrm{BF}^{-}\right)$and treated with 1.5 equiv of Dess-Martin periodinane for $3 \mathrm{~h}$ to afford the corresponding aldehyde 11. Extraction of the product from the ionic liquid with diethyl ether resulted in the isolation of a single product as a solid which was identified with MS and ${ }^{1} \mathrm{H}$ NMR as the desired aldehyde 11 . Because of its propensity for epimerization, 11 was used directly in the $C$-glycosylation reaction without further analysis or purification. $C$-Glycosylation of $\mathbf{1 1}$ used Neu5Ac sulfone donor $\mathbf{1 2}$ (1.25 equiv) in the presence of $\mathrm{SmI}_{2}$ (6 equiv) in THF (Scheme 2). A modest $25 \%$ yield of the desired $C$ glycoside product $\mathbf{1 3}$ was obtained.

The HRMS of the compound $\mathbf{1 3}$ gave a clear $\mathrm{m} / z[\mathrm{M}+\mathrm{Na}]^{+}$base peak at 919.2883 corresponding to the chemical formula of $\mathrm{C}_{41} \mathrm{H}_{53} \mathrm{ClN}_{2} \mathrm{NaO}_{18}$ consistent with structure. The structural and conformational analysis of compound $\mathbf{1 3}$ was determined by NMR spectroscopy and molecular modeling (SYBYL 6.6 on a SGI interface using a TRIPOS force field and a dielectric constant set to 4.8). ${ }^{1} \mathrm{H}$ NMR showed a disaccharide product having identifiable resonances corresponding to $-\mathrm{CO}_{2} \mathrm{Me},-\mathrm{OAc},-\mathrm{NHAc},\left(\mathrm{CH}_{3}\right)_{2} \mathrm{C}-$, and allyl. ${ }^{1} \mathrm{H}-{ }^{1} \mathrm{H}$ COSY was used to make proton assignments. NOE spectroscopy showed strong through-space interaction between H-6 of galactosamine with H-4 and H-5 of galactosamine as well as H-3ax of Neu5Ac. The H-6 GalNAcBzfH $\rightarrow 3 a x$ Neu5Ac 
interaction was consistent with the expected a-configuration of the anomeric center. The signal corresponding to the resonance of $\mathrm{H}-6$ in GalNAcBz in the ${ }^{1} \mathrm{H}$ NMR spectrum of $\mathbf{1 3}$ is a doublet. $\mathrm{H}-6$ is coupled with the $\mathrm{C} 6-\mathrm{OH}$ hydroxyl proton, with a $J_{\mathrm{H}, \mathrm{OH}}$ of $6.4 \mathrm{~Hz}$ and no coupling is observed between H-6 and H-5 of GalNAcBz. According to the molecular models the value of the H6-C6-C5-H5 torsion angle in the $S$ and $R$ isomers is -59.1 and $-177.0^{\circ}$, respectively. The absence of coupling between H-6 and H-5 is in agreement with the presence of the $S$ isomer, where the torsion angle is closer to 90 degrees. In the ${ }^{1} \mathrm{H}$ NMR spectrum of the $R$ isomer the H-6 resonance signal would clearly show coupling with H-5 but no such coupling was observed. Thus, we conclude that the $S$ isomer is formed with complete diastereocontrol in $C$-glycosylation was consistent with our previous results on the a $(2 \rightarrow 3) C$-glycosylation. ${ }^{4 b}$

Fully protected sTn double $C$-glycoside $\mathbf{1 3}$ was next deprotected in three steps, deisopropylidenation with $60 \%$ acetic acid at $80{ }^{\circ} \mathrm{C}$ for $1 \mathrm{~h}$, followed by deacylation with $\mathrm{NaOMe}$ and $\mathrm{MeOH}$ and demethylation using $0.1 \mathrm{KOH}$ affording 2 in quantitative yield.

Studies are underway to conjugate the sTn double $C$-glycoside hapten $\mathbf{2}$ to KLH carrier protein for biological evaluation as a vaccine.

\section{Experimental Section}

\section{1-(2'-Acetamido-2'-deoxy-6-[(tert-butyl(diphenyl)silyl]-a-D-galactopyranosyl)prop-2-ene (7)}

tert-Butyldiphenyl silyl chloride (1.4 mL, $7.95 \mathrm{mmol}$ ) was added to a solution of $\mathbf{3}$ (1.3 g, $5.3 \mathrm{mmol})$ in DMF $(5 \mathrm{~mL})$ in the presence of imidazole $(360 \mathrm{mg}, 5.3 \mathrm{mmol})$. The reaction mixture was stirred at room temperature for $5 \mathrm{~h}$ and evaporated under reduced pressure. Purification of the residue by flash chromatography (hexane/EtOAc 4:1) yielded 7 (1.48 g, 58\%): ${ }^{1} \mathrm{H}$ NMR (400 MHz, $\left.\mathrm{CDCl}_{3}\right) \delta 7.69-7.65(\mathrm{~m}, 4 \mathrm{H}), 7.44-7.37(\mathrm{~m}, 6 \mathrm{H})$, 5.78-5.66 (m, $2 \mathrm{H}), 5.08-5.03(\mathrm{~m}, 2 \mathrm{H}), 4.33-4.22(\mathrm{~m}, 2 \mathrm{H}), 4.09(\mathrm{bs}, 1 \mathrm{H}), 3.94-3.83(\mathrm{~m}, 2 \mathrm{H}), 3.70(\mathrm{bs}, 2 \mathrm{H})$, $3.14(\mathrm{~d}, 1 \mathrm{H}, J) 8 \mathrm{~Hz}$ ), 2.89 (d, 1H, J ) $5.2 \mathrm{~Hz}), 2.32-2.17$ (m, 2H), 2.01 (s, 3H), 1.06 (s, 9H); ESI-MS $484[\mathrm{M}+\mathrm{H}]^{+}, 482[\mathrm{M}-\mathrm{H}]^{-}$.

\section{1-\{(2'-Acetamido-2' -deoxy-3,4-diisopropylidine-6-[(tert-butyl(diphenyl)silyl]-a-D- galactopyranosyl\}prop-2-ene (8)}

Dimethoxypropene $(1.4 \mathrm{~mL}, 7.95 \mathrm{mmol})$ was added to a solution of $7(1.0 \mathrm{~g}, 2.07 \mathrm{mmol})$ in DMF $(5 \mathrm{~mL})$ in the presence of catalytic amount Amberlite IR-120 $\left(\mathrm{H}^{+}\right)$. The reaction mixture was stirred at room temperature for $12 \mathrm{~h}$, filtered, and evaporated under reduced pressure. Purification of the residue by flash chromatography (hexane/EtOAc 4:1) yielded 8 (1.07 g, quant.). ${ }^{1} \mathrm{H}$ NMR (400 MHz, $\left.\mathrm{CDCl}_{3}\right) \delta 7.72-7.67(\mathrm{~m}, 4 \mathrm{H}), 7.45-7.35(\mathrm{~m}, 6 \mathrm{H})$, 5.70-5.56 (m, 2H), 5.07-5.03 (m, 2H), 4.52-4.50 (m, 1H), 4.26-4.24 (m, 1H), $4.12(\mathrm{~m}, 1 \mathrm{H})$, 3.91-3.79 (m, 4H), 2.35-2.22 (m, 1H), 2.18-2.03 (m, 1H), 2.01 (s, 3H), $1.48(\mathrm{~s}, 3 \mathrm{H}), 1.32$ (s, 3H), $1.05(\mathrm{~s}, 9 \mathrm{H})$; ESI-MS $524[\mathrm{M}+\mathrm{H}]^{+}, 522[\mathrm{M}-\mathrm{H}]^{-}$. 


\section{1-\{(2'-Acetyl-2' -p-chlorobenzoyl)amino-2' - deoxy-3,4-di-isopropylidine-6-[(tert- butyl(diphenyl)silyl]-a-D-galacto-pyranosyl\}prop-2-ene (9)}

Compound 8 (380 mg, $0.73 \mathrm{mmol}$ ) was dissolved in $2 \mathrm{~mL}$ of pyridine-dichloromethane (1:1) mixture at $0{ }^{\circ} \mathrm{C}$, and $p$-chlorobenzoyl chloride $(184 \mu \mathrm{L}, 1 \mathrm{mmol})$ was added. After $10 \mathrm{~min}$ at $0{ }^{\circ} \mathrm{C}$, reaction mixture was stirred at room temperature overnight, poured into ice-water, and extracted with $\mathrm{CHCl}_{3}$. The organic phase was washed with $\mathrm{NaHCO}_{3}$ and water, dried over $\mathrm{MgSO}_{4}$, filtered, and evaporated. The residue was purified on a silica gel column (petroleum ether-ethyl acetate v/v 6:1) to afford $9(456 \mathrm{mg}, 95 \%):{ }^{1} \mathrm{H}$ NMR $\left(500 \mathrm{MHz}, \mathrm{CDCl}_{3}\right) \delta 7.75-$ $7.63(\mathrm{~m}, 6 \mathrm{H}), 7.45-7.31$ (m, 8H), 5.77 (m, 1H, H-2), 5.17-4.96 (m, 3H, H-3a, H-3b, H-3'), 4.74 (dd, $\left.1 \mathrm{H}, J=8, J=14.5, \mathrm{H}-2^{\prime}\right), 4.44\left(\mathrm{dd}, 1 \mathrm{H}, J=4, J=9, \mathrm{H}-4^{\prime}\right), 4.14-3.93$ (m, 3H, H-1', H-5", H-6'a), 3.81 (dd, 1H, $J=10, J=15.5$, H-6'b), 2.53 (m, 1H, H-1a), 2.32 (m, 1H, $\mathrm{H}-1 \mathrm{~b}), 1.91$ (s, $\left.3 \mathrm{H}, \mathrm{NCOCH}_{3}\right), 1.52$ and $1.29\left(\mathrm{~s}, 2 \times 3 \mathrm{H}, 2 \times \mathrm{CH}_{3}\right), 1.05(\mathrm{~s}, 9 \mathrm{H}$, tert-butyl); 13C NMR (300 MHz, $\left.\mathrm{CDCl}_{3}\right) \delta 173.9,173.2,135.8,135.9,134.9,134.5,133.8,133.7$, 130.9, 129.8, 129.6, 127.8, 127.8, 117.1, 109.3, 73.4, 73.3, 70.7, 69.1, 63.3, 60.4, 32.4, 28.5, 27.6, 26.9, 26.3, 19.4, 1.2; ESI-MS $662.2[\mathrm{M}+\mathrm{H}]^{+}, 684.2[\mathrm{M}+\mathrm{Na}]^{+}$; HRMS calcd for $\mathrm{C}_{37} \mathrm{H}_{44} \mathrm{ClNNaO}_{6} \mathrm{Si}[\mathrm{M}+\mathrm{Na}]^{+}$684.2524, found $m / 2684.2533[\mathrm{M}+\mathrm{Na}]^{+}$.

\section{1-[(2' -Acetyl-2' - p-chlorobenzoyl)amino-2' -deoxy-3,4-di-isopropylidine-a-D-} galactopyranosyl]prop-2-ene (10)

Compound 9 (30 mg, $0.045 \mathrm{mmol}$ ) was dissolved in $1 \mathrm{~mL}$ of anhydrous THF, and trihydrofluoride triethylamine $(300 \mu \mathrm{L})$ was added. The reaction mixture was stirred at room temperature. After $3 \mathrm{~h}$, additional trihydrofluoride triethylamine $(500 \mu \mathrm{L})$ was added and the mixture stirred for an additional $4 \mathrm{~h}$. The reaction mixture was dropped into cold $\mathrm{NaHCO}_{3}$ and extracted with $\mathrm{Et}_{2} \mathrm{O}$. The combined organic phase was washed with water, dried over $\mathrm{MgSO}_{4}$, filtered, and evaporated. The residue was purified on a silica gel column (petroleum ether-ethyl acetate v/v 5:1) to afford $10(17 \mathrm{mg}, 88 \%):{ }^{1} \mathrm{H} \mathrm{NMR}\left(500 \mathrm{MHz}, \mathrm{CDCl}_{3}\right) \delta 7.67$ (d, 2H), $7.42(\mathrm{~d}, 2 \mathrm{H}), 5.81(\mathrm{~m}, 1 \mathrm{H}), 5.20-4.98(\mathrm{~m}, 3 \mathrm{H}), 4.72(\mathrm{bs}, 1 \mathrm{H}), 4.36(\mathrm{bs}, 1 \mathrm{H}), 4.20$ $3.62(\mathrm{~m}, 4 \mathrm{H}), 2.51(\mathrm{~m}, 1 \mathrm{H}), 2.36(\mathrm{~m}, 1 \mathrm{H}), 1.92(\mathrm{~s}, 3 \mathrm{H}), 1.52$ and $1.29(\mathrm{~s}, 2 \times 3 \mathrm{H})$; ESI-MS $424.1[\mathrm{M}+\mathrm{H}]^{+}, 446.1[\mathrm{M}+\mathrm{Na}]+$; HRMS calcd for $\mathrm{C}_{21} \mathrm{H}_{26} \mathrm{ClNO}_{6}[\mathrm{M}+\mathrm{H}]^{+} 424.1527$, found $m / z 424.1521[\mathrm{M}+\mathrm{H}]^{+}$.

\section{1-[(2'-Acetyl-2' -p-chlorobenzoyl)amino-2' -deoxy-3,4-di-isopropylidine-5-formyl-a-D- galactopyranosyl]prop-2-ene (11)}

Compound 10 ( $33 \mathrm{mg}, 0.078 \mathrm{mmol}$ ) was placed into a $5 \mathrm{~mL}$ round-bottom flask along with $500 \mu \mathrm{L}$ of butylmethylimidazolium tetrafluoroborate (bmim[BF 4 ) under high vacuum for 2 h. Dess-Martin periodinane (1.5 equiv) was added. The reaction mixture was stirred under argon for $3 \mathrm{~h}$, poured into water, and extracted with diethyl ether. The organic phases were combined and suction filtered through a pad of Celite/ $\mathrm{NaHCO}_{3}$ (1:1 by mass). The filtrate was dried over $\mathrm{MgSO}_{4}$ and concentrated under reduced pressure. A $32 \mathrm{mg}$ amount of $\mathbf{1 1}$ was isolated and used for the next step without any further purification: 1H NMR $(500 \mathrm{MHz}$, $\left.\mathrm{CDCl}_{3}\right) \delta 9.62(\mathrm{~s}, 1 \mathrm{H}), 7.68(\mathrm{~d}, 2 \mathrm{H}), 7.45(\mathrm{~d}, 2 \mathrm{H}), 5.89(\mathrm{~m}, 1 \mathrm{H}), 5.17-5.02(\mathrm{~m}, 3 \mathrm{H}), 4.80-$ $4.62(\mathrm{~m}, 2 \mathrm{H}), 4.34-3.73(\mathrm{~m}, 4 \mathrm{H}), 2.50-2.31(\mathrm{~m}, 2 \mathrm{H}), 1.91(\mathrm{~s}, 3 \mathrm{H}), 1.50$ and $1.30(\mathrm{~s}, 2 \times 3 \mathrm{H})$; ESI-MS $422.1[\mathrm{M}+\mathrm{H}]^{+}$. 


\section{Methyl 5-Acetamido-4,7,8,9-tetra-O-acetyl-2,6-anhydro-3,5-dideoxy-2-C-\{(S)-hydroxy-[6- ((2'-acetyl-2' - p-chlorobenzoyl)amino-2' -deoxy-3,4-diisopropylidine-1-(1-prop-2-enyl)-a-D- galactopyranosyl)]methyl\}-D-erythro-L-manno-nononate (13)}

A solution of compounds 11 (22 mg, $0.05 \mathrm{mmol})$ and 12 (40 mg, $0.065 \mathrm{mmol})$ in $\mathrm{CH}_{2} \mathrm{Cl}_{2}$ (2 $\mathrm{mL}$ ) was evaporated to dryness and the resulting residue dried overnight under high vacuum. To the dried residue placed under argon was added a solution of freshly prepared $\mathrm{SmI}_{2}(0.1$ $\mathrm{M}, 5 \mathrm{~mL}$ ), and the reaction mixture was stirred at room temperature for $20 \mathrm{~min}$. The reaction mixture was then diluted with ether, washed successively with ${ }_{1} \mathrm{~N} \mathrm{HCl}$, saturated aqueous $\mathrm{Na}_{2} \mathrm{~S}_{2} \mathrm{O}_{3}$, and $\mathrm{H}_{2} \mathrm{O}$, dried over anhydrous $\mathrm{MgSO}_{4}$, and filtered, and the solvents were evaporated. The residue was purified by chromatography on silica gel (petroleum ether-ethyl acetate, v/v 4:1 to 1:1) to give $\mathbf{1 3}(12 \mathrm{mg}, 25 \%)$ : $\left.1 \mathrm{H} \mathrm{NMR} \mathrm{(500} \mathrm{MHz}, \mathrm{CDCl}_{3}\right) \delta 7.69$ (d, 2H, $J=8.6 \mathrm{~Hz}), 7.45(\mathrm{~d}, 2 \mathrm{H}, J=8.6 \mathrm{~Hz}), 5.81\left(\mathrm{~m}, 1 \mathrm{H}, \mathrm{H}-2^{\prime \prime}\right), 5.35(\mathrm{ddd}, 1 \mathrm{H}, J=2.6 \mathrm{~Hz}, J=6.8$ $\mathrm{Hz}, J=7.4 \mathrm{~Hz}, \mathrm{H}-8), 5.30$ (dd, $1 \mathrm{H}, J=2.1 \mathrm{~Hz}, J=7.4 \mathrm{~Hz}, \mathrm{H}-7), 5.11-5.00$ (m, 3H, H-3”a, H-3"'b, H-3'), 4.81-4.70 (m, 2H, H-4, H-2'), 4.38 (d, 1H, $\left.J=3.1 \mathrm{~Hz}, \mathrm{H}-4^{\prime}\right), 4.35$ (dd, 1H, $J=$ $2.6 \mathrm{~Hz}, J=12.6 \mathrm{~Hz}, \mathrm{H}-9 \mathrm{a}), 4.15-4.00$ (m, 5H, H-9b, H-1', H-6, H-5, H-5'), 3.93 (d, 1H, $J=$ $\left.6.4 \mathrm{~Hz}, \mathrm{H}-6^{\prime}\right), 3.66$ (s, 3H, $\mathrm{COOCH}_{3}$ ), 3.18 (d, 1H, $\left.J=6.4 \mathrm{~Hz}, \mathrm{C}^{\prime}-\mathrm{OH}\right), 2.84$ (dd, $1 \mathrm{H}, J=$ $4.4 \mathrm{~Hz}, J=13.2 \mathrm{~Hz}, \mathrm{H}-3 \mathrm{eq}$ ), 2.48 (dd, $2 \mathrm{H}, J=6.9 \mathrm{~Hz}, J=6.9 \mathrm{~Hz}, \mathrm{H}-1$ "a, H-1"b), 2.15, 2.12, 2.08, 2.03 (4s, 4 OAc), 1.86 (m, 4H, NAc, H-3ax), 1.83 (s, 3H, NAc), 1.52 and 1.35 (s, $2 \times$ $3 \mathrm{H}, 2 \times \mathrm{CH}_{3}$ ); ESI-MS $897.3[\mathrm{M}+\mathrm{H}]^{+}, 919.3[\mathrm{M}+\mathrm{Na}]^{+}$; HRMS calcd for $\mathrm{C}_{41} \mathrm{H}_{53} \mathrm{ClN}_{2} \mathrm{NaO}_{18}[\mathrm{M}+\mathrm{Na}]^{+} 919.2880$, found $m / z$. $919.2883[\mathrm{M}+\mathrm{Na}]^{+}$.

\section{5-Acetamido-2,6-anhydro-3,5-dideoxy-2-C-\{(S)-hydroxy-[6-(2' -acetyl-2' -deoxy-1-(1-prop-2- enyl)-a-D-galactopyranosyl)]methyl\}-D-erythro-L-manno-nononate (2)}

Fully protected sTn double $C$-glycoside $13(9 \mathrm{mg}, 0.01 \mathrm{mmol})$ and $60 \%$ acetic acid $(2 \mathrm{~mL})$ were stirred at $80{ }^{\circ} \mathrm{C}$ for $1 \mathrm{~h}$. The reaction mixture was extracted with $\mathrm{CHCl}_{3}$, and the organic phase was combined, dried over $\mathrm{MgSO}_{4}$, filtered, and evaporated. The dried residue was reacted with a catalytic amount $\mathrm{NaOMe}$ in methanol overnight followed by stirring with $0.1 \mathrm{M} \mathrm{KOH}$ another overnight. The resulting mixture was neutralized with Amberlite IR-120 $\left(\mathrm{H}^{+}\right)$exchange resin and filtered and the solvent evaporated to dryness. The residue was passed through a P2 desalting column. Fractions were collected, evaporated under high vacuum, redissolved in water, and lyophilized to give a white powder in quantitative yield: 1H NMR (500 MHz, D $2 \mathrm{O}) \delta 5.81$ (m, 1H, H-2"), 5.09-5.02 (m, 2H, H-3"a, H-3"b), 4-573.53 (m, 12H), 2.84 (dd, 1H, $J=4 \mathrm{~Hz}, J=13.5 \mathrm{~Hz}, \mathrm{H}-3 \mathrm{eq}), 2.49$ (m, 1H, H-1"a), 2.35 (m, 1H, H-1”b), 1.96, 1.92 (2s, $2 \times 3 \mathrm{H}, \mathrm{NAc}), 1.71$ (t, 1H, $J=12.5$, H-3ax); ESI-MS 535.3 [M $\mathrm{H}]^{-}, 559.3[\mathrm{M}+\mathrm{Na}]^{+} ;$HRMS calcd for $\mathrm{C}_{22} \mathrm{H}_{36} \mathrm{~N}_{2} \mathrm{NaO}_{13}[\mathrm{M}+\mathrm{Na}]^{+} 559.2115$, found $\mathrm{m} / z$ $559.2113[\mathrm{M}+\mathrm{Na}]^{+}$.

\section{Supplementary Material}

Refer to Web version on PubMed Central for supplementary material.

\section{References}

(1). Schauer R. Adv. Carbohydr. Chem. Biochem. 1982; 40:131. [PubMed: 6762816]

(2). Varki A. Glycobiology. 1992; 2:25. [PubMed: 1550987] 
(3). Swartley JS, Marfin AA, Edupugantis D, Liu LJ, Cieslak P, Perkins B, Wenger JD, Stephans DS. Proc. Nat. Acad. Sci. U.S.A. 1997; 94:271.

(4). (a) Vlahov IR, Vlahova PI, Linhardt RJ. J. Am. Chem. Soc. 1997; 119:1480.(b) Bazin HG, Du Y, Polat T, Linhardt RJ. J. Org. Chem. 1999; 64:7254.(c) Du Y, Polat T, Linhardt RJ. Tetrahedron Lett. 1998; 39:5007.

(5). Du Y, Linhardt RJ, Vlahov IR. Tetrahedron. 1998; 54:9913.

(6). (a) Livingston P. Cancer Biol. 1995; 6:357.(b) Deng S-J, Mackenzie CR, Hirama T, Brousseau R, Lowary TL, Bundle DR, Narang SA. Proc. Nat. Acad. Sci. U.S.A. 1995; 92:4992. N. M., Y. (c) Kuberan B, Linhardt RJ. Curr. Org. Chem. 2000; 4:653.

(7). Mouritsen S, Meldal M, Christiansen-Brams I, Elsner H, Werdelin O. Eur. J. Immunol. 1994; 24:1066. [PubMed: 8181518]

(8). Kenne, L. Bacterial polysaccharides. Academic Press; New York: 1983. L. B.

(9). Livingston PO. Ann. N. Y. Acad. Sci. 1993; 690:204. [PubMed: 8368739]

(10). Herrler G, Gross HJ, Brossmer R. Biochem. Biophys. Res. Commun. 1995; 216:821. [PubMed: 7488199]

(11). Kaijser B, Jodal U. J. Clin. Microbiol. 1984; 19:264. [PubMed: 6199369]

(12). (a) Toyokuni T, Singhal A. Chem. Soc. Rev. 1995:231.(b) Maclean G, Longenecker B. Can. J. Oncol. 1994; 4:249. [PubMed: 7516257] (c) Livingston PO. Curr. Opin. Immunol. 1992; 4:624. [PubMed: 1418730]

(13). (a) Hansen JE, Clausen H, Nielsen C, Teglbjaerg S, Hansen LH, Nielsen CM, Dabelsteen E, Mathiesen L, Hakomori SI, Nielsen JO. J. Virol. 1990; 64:2833. [PubMed: 1692349] (b) Hansen JES, Jansson B, Gram GJ, Clausen H, Nielsen JO, Olofsson S. Arch. Virol. 1996; 141:291. [PubMed: 8634021] (c) Miyajima K, Nekado T, Ikeda K, Achiwa K. Chem. Pharm. Bull. 1997; 45:1544. [PubMed: 9332007] (d) Miyajima K, Nekado T, Ikeda K, Achiwa K. Chem. Pharm. Bull. 1998; 46:1676. [PubMed: 9845951]

(14). (a) Itzkowitz SH, Yuan M, Montgomery CK, Kjeldsenen T, Takahashi HK, Bigbee WL, Kim YS. Cancer Res. 1989; 49:197. [PubMed: 2908846] (b) Hakomori SI. Cancer Res. 1989; 49:257.

(15). Harris JR, Markl J. Micron. 1999; 30:597. [PubMed: 10544506]

(16). Zhang S, Walberg LA, Ogata S, Itzkowitz SH, Koganty RR, Reddish M, Gandhi SS, Longenecker BM, Lloyd KO, Livingston PO. Cancer Res. 1995; 55:3364. [PubMed: 7614472]

(17). Kuberan B, Sikkander SA, Tomiyama H, Linhardt RJ. Angew. Chem., Int. Ed. 2003; 42:2073.

(18). Cipolla L, Ferla BL, Lay L, Peri F, Nicotra F. Tetrahedron: Asymmetry. 2000:295.

(19). Yu C, Niikura K, Lin C, Wong CH. Angew. Chem., Int. Ed. 2001; 40:2900.

(20). Yadav JS, Reddy BVS, Basak AK, Narsaiah AV. Tetrahedron. 2004; 60:2131.

(21). Murugesan S, Karst NA, Islam T, Wiencek JM, Linhardt RJ. Synlett. 2003; 9:1283. 

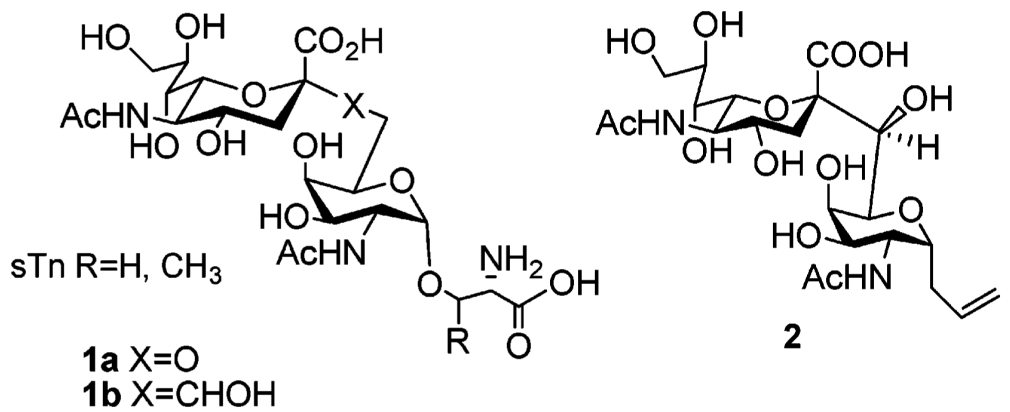

FIGURE 1.

Tumor-associated antigens and the double $C$-glycoside analogue. 


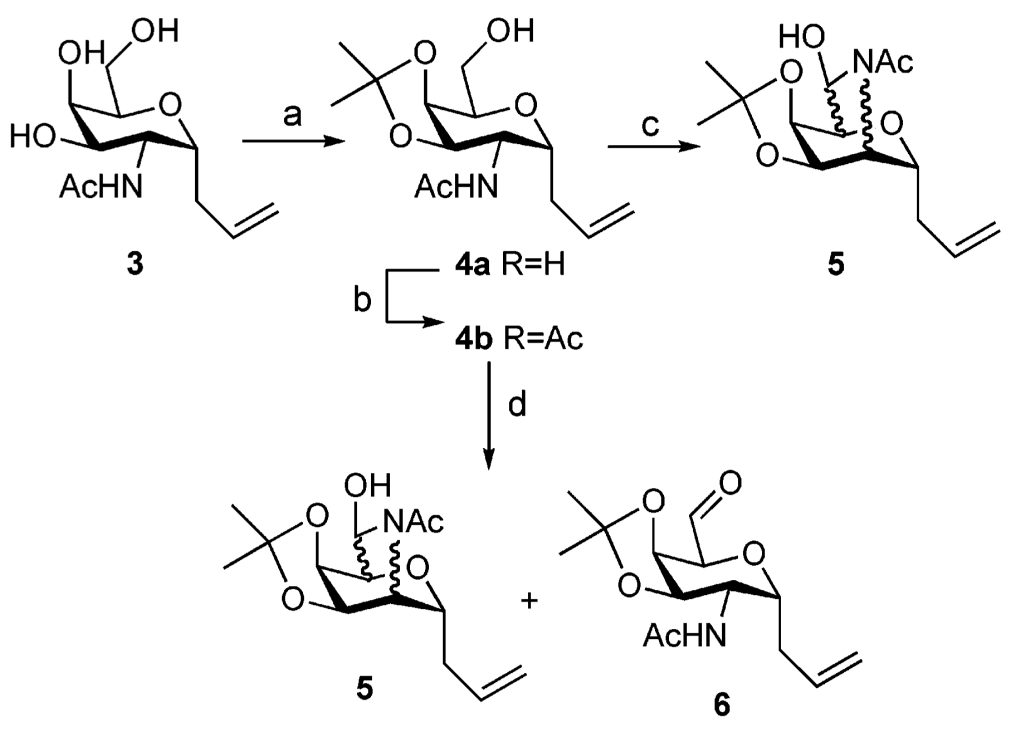

SCHEME 1. Synthesis of 6-Formyl Galactoside 6 with Unexpected Product Hemiaminal $5^{a}$

${ }^{a}$ Key: (a) (i) TBDPSCl, imidazole, DMF, rt, 5 h, $58 \%$, (ii) $\mathrm{Me}_{2} \mathrm{C}(\mathrm{OMe})_{2}$, Amberlite IR-120 (H+) (cat.), DMF, rt, 12 h, (iii) $\mathrm{NEt}_{3} \cdot 3 \mathrm{HF}, \mathrm{THF}, \mathrm{rt}, 7 \mathrm{~h}, 88 \%$; (b) $\mathrm{Ac}_{2} \mathrm{O}, \mathrm{Pyr}$, rt, overnight; (c) oxalyl chloride, DMSO, $\mathrm{CH}_{2} \mathrm{Cl}_{2} / \mathrm{NEt}_{3},-78{ }^{\circ} \mathrm{C}, 65 \%$; (d) Dess-Martin periodinane, $\mathrm{CH}_{2} \mathrm{Cl}_{2}$, rt, $7 \mathrm{~h}$. 


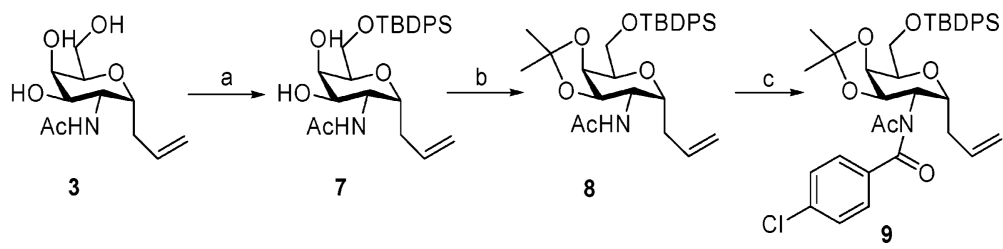

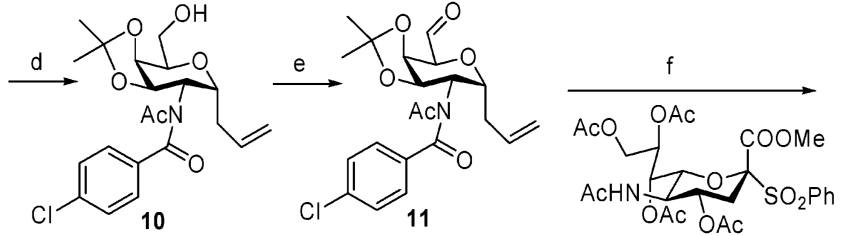

12

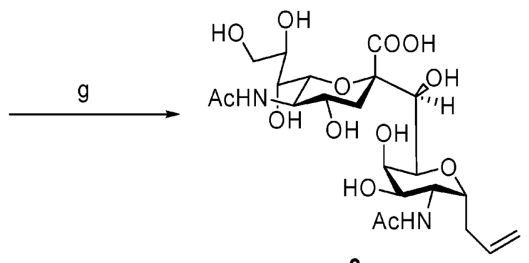

2

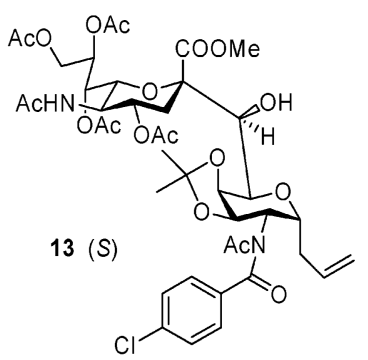

SCHEME 2. Synthesis of sTn Double $\boldsymbol{C}$-Glycoside $\mathbf{2}^{\mathbf{a}}$

${ }^{a}$ Key: (a) TBDPSCl, imidazole, DMF, rt, 5 h, 58\%; (b) $\mathrm{Me}_{2} \mathrm{C}(\mathrm{OMe})_{2}$, Amberlite IR-120 (H +) (cat), DMF, rt, $12 \mathrm{~h}$, quantitative; (c) $p$-chlorobenzoyl chloride, $\mathrm{Pyr}-\mathrm{CH}_{2} \mathrm{Cl}_{2}$ (1:1), DMAP, rt, overnight, 91\%; (d) $\mathrm{NEt}_{3} \cdot 3 \mathrm{HF}$, THF, rt, 7h, 88\%; (e) Dess-Martin periodinane, [bmim $]^{+} \mathrm{BF}^{-}, \mathrm{rt}, 3 \mathrm{~h}$; (f) $\mathrm{SmI}_{2}, \mathrm{THF}, 25 \%$; (g) (i) $60 \% \mathrm{AcOH}, 80{ }^{\circ} \mathrm{C}, 1 \mathrm{~h}$, (ii) $\mathrm{NaOMe}$ (cat.), $\mathrm{MeOH}$, rt, overnight, (iii) $0.1 \mathrm{KOH}$, rt, overnight. 